\title{
Peningkatan Kelarutan Glukomanan Porang (Amorphophallus muelleri Blume) dengan Penggilingan Basah dan Kering
}

\author{
Porang (Amorphophallus muelleri Blume) Glucomannan Solubility Increase by Wet dan Dry Milling
}

\author{
Anny Yanuriati ${ }^{1 *}$, Dasril Basir ${ }^{2}$ \\ ${ }^{1}$ Program Studi Teknologi Hasil Pertanian, Fakultas Pertanian, Universitas Sriwijaya, \\ Jl. Raya Palembang-Prabumulih Km. 32, Indralaya-Ogan Ilir, Sumatera Selatan 30662, Indonesia \\ 2Jurusan Kimia, Fakultas MIPA Universitas Sriwijaya, \\ Jl. Raya Palembang-Prabumulih Km. 32, Indralaya-Ogan Ilir, Sumatera Selatan 30662, Indonesia \\ *Penulis korespondensi: Anny Yanuriati, E-mail: annyyanuriati@fp.unsri.ac.id
}

Tanggal submisi: 19 Februari 2019; Tanggal penerimaan: 20 Maret 2020

\begin{abstract}
ABSTRAK
Meskipun hidrofilik, kelarutan glukomanan sangat lambat sehingga peningkatan kelarutannya diperlukan agar aplikasinya dapat lebih luas, mudah dan cepat. Penelitian ini bertujuan mendapatkan metode penggilingan yang dapat meningkatkan kelarutan glukomanan dengan transparansi, water holding capacity (WHC) dan viskositas apparenttetap tinggi. Ekstrak granula glukomanan dari porang dibagi menjadi 3 perlakuan, alami tanpa penggilingan (natif), digiling sampai lolos saringan 80 mesh (penggilingan kering) atau sebelum penggilingan, terlebih dahulu dilarutkan, dipresipitasi dengan ethanol (penggilingan basah) selanjutnya dikeringkan dan diayak sampai lolos saringan 80 mesh. Penggilingan basah dapat meningkatkan kelarutan glukomanan secara signifikan lebih tinggi (18\%) dibandingkan dengan penggilingan kering (13\%) dengan transparansi, WHC dan viskositas apparent yang masih tinggi akibat depolimerisasi, penurunan berat molekul disertai perubahan morfologi glukomanan menjadi lebih berpori dan amorf.
\end{abstract}

Kata kunci: Kering; glukomanan; penggilingan; pengecilan ukuran; basah

\begin{abstract}
Despite of hydrophilic, glucomannan solubility is so slow that its solubility increase is required for easier, faster, and wider application. This research objective was to find a milling method which can enhance glucomannan solubility with high sol transparency, WHC and apparent viscosity. Native glucomannan extract from porang corm was classified into 3 treatments, no milling (native), grinding to pass through 80 mesh sieve (dry milling) or before grinding, the glucomannan were dissolved and precipitated using ethanol (wet milling) which then dried and passed through 80 mesh sieve. Compared to dry milling (13\%), wet milling could significantly enhance higher glucomannan solubility (18\%) with high sol transparency, WHC and apparent viscosity due to its depolymerization, molecular weight reduction, more porous and amorphous morphology as well.
\end{abstract}

Keywords: Dry; glucomannan; milling; size reduction; wet 


\section{PENDAHULUAN}

Umbi porang (Amorphophallus muelleri Blume) merupakan salah satu sumber glukomanan potensial di Indonesia. Tanaman tersebut saat ini dibudidayakan dan dikembangkan untuk memenuhi permintaan ekspor yang semakin meningkat setiap tahun. Padahal sebelumnya, porang tidak diperhatikan dan belum pernah dimanfaatkan oleh masyarakat karena mengandung kalsium oksalat yang tinggi sehingga tidak dapat langsung dikonsumsi. Glukomanan harus diisolasi dulu dari umbi sebelum dimanfaatkan dengan proses isolasi yang tidak sederhana.

Glukomanan sangat banyak manfaatnya, baik untuk pangan, kesehatan (Tester dan Al-Ghazzewi, 2013), kosmetik, farmasi (Behera dkk., 2016; Chua dkk., 2010; Zhang dkk., 2014, Alonso-Sdane dkk., 2009) dan berbagai industri kimia (Zhang dkk., 2005). Salah satu yang membatasi aplikasi glukomanan alami adalah kelarutannya yang rendah (Pan dkk., 2013) meskipun bersifat hidrofilik (Pan dkk., 2013; Zhao dkk., 2010; Li dkk., 2014) sehingga perlu ditingkatkan agar polimer ini mudah diaplikasikan secara luas. Selain berat molekul, keberadaan asetil, gugus cabang dan gugus samping juga akan mempengaruhi kelarutan glukomanan. Beberapa penelitian sebelumnya melakukan beberapa upaya peningkatan kelarutan glukomanan dengan cara modifikasi secara fisik (Li dkk., 2005), kimia dengan asetilasi (Gao dan Nishinari, 2004; Liu dkk., 2012), metilasi (An dkk., 2011a), karboksimetilasi (An dkk., 2011b), enzimatis (Xing dkk., 2015), depolimerisasi dengan iradiasi sinar gamma atau bersama hidrogen peroksida (Pan dkk., 2013), ekstrusi (Tatirat dkk., 2013) dan ultrasonikasi (Pan dkk., 2013).

Pengecilan ukuran dengan penggilingan merupakan salah satu cara yang dapat mempercepat pelarutan glukomanan. Ukuran yang lebih kecil memiliki permukaan lebih luas sehingga lebih mudah terhidratasi dan cepat larut. Wang dkk. (2010), mendapatkan bahwa ukuran 80-100 mesh memiliki polaritas maksimal. Namun, glukomanan bersifat sangat keras dan tidak mudah dihancurkan (Zhao dkk., 2010). Penggilingan pada kecepatan tinggi akan menghasilkan friksi antar granula glukomanan dan juga antar granula dengan pisau penggiling yang pada periode tertentu menghasilkan panas. Pada periode kritis, panas kumulatif tersebut dapat mulai mendegradasi warna glukomanan yang putih tulang menjadi lebih gelap, sehingga tranparansi serta viskositas sol glukomanan tersebut dapat menurun secara signifikan (Ohashi dkk., 2000).

Penggilingan glukomanan selama ini dilakukan pada kondisi kering dengan kecepatan tinggi. Pada penelitian ini penggilingannya dimodifikasi dengan metode basah, merubah bentuk glukomanan dari granula kering menjadi presipitat glukomanan basah parsial. Rantai glukomanan tersebut juga lebih mengembang dan terbuka serta ikatan hidrogen inter dan intra molekul glukomanan lebih lemah. Pada kondisi ini glukomanan dapat digiling dengan mudah dan cepat sehingga penurunan mutunya dapat diminimalisasi secara signifikan. Depolimerisasi yang teroksidasi dan pembentukan ikatan hidrogen yang kuat selama pengeringan dapat diperkecil. Penggilingan basah glukomanan diharapkan akan mudah dilakukan dengan proses yang lebih cepat sehingga dapat meningkatkan kelarutan dan meminimalisasi penggelapan warna maupun penurunan transparansi dan viskositas. Penelitian proses penggilingan glukomanan dengan cara kering dan basah dilakukan dan dibandingkan karakteristiknya dengan glukomanan alami tanpa penggilingan. Penelitian ini bertujuan mendapatkan metode penggilingan yang dapat meningkatkan kelarutan glukomanan dengan transparansi, WHC dan viskositas apparent tetap tinggi.

\section{METODE PENELITIAN}

\section{Bahan dan Alat}

Bahan yang digunakan adalah umbi porang sekitar 2-3 minggu pasca panen dalam kondisi baik dan berumur sekitar 3 tahun dari Desa Klangon, Madiun; etanol teknis 96\% dan akuademin dibeli dari Brataco. Alat yang digunakan berupa blender 'Philips', Oven, viscometer 'Brookfield', agitator, Scanning Electrone Microscope (SEM), spectrometer UV-vis dan tampak,sentrifuge dan neraca analitik.

\section{Preparasi Bahan}

Umbi porang yang telah bersih dipotong, digiling dalam etanol $50 \%$ dan disaring secara berulang kali. Penggilingan menggunakan blender berkecepatan no 1 . Ekstrak glukomanan tersebut dikeringkan dalam oven bersuhu $45^{\circ} \mathrm{C}$. Selanjutnya, glukomanan dikelompokkan menjadi 3 perlakuan, alami tanpa digiling (natif) atau digiling dan diayak sampai lolos saringan 80 mesh (penggilingan kering) atau digiling setelah pelarutan dan presipitasi dengan etanol (penggilingan basah), dikeringkan dan diayak sampai lolos saringan 80 mesh. Glukomanan natif, penggilingan kering dan penggilingan basah tersebut dianalisa morfologi, kelarutan, WHC, tranparansi dan viskositas apparent.

\section{Analisis Morfologi Permukaan Glukomanan}

Morfologi permukaan glukomanan hasil penggilingan dianalisa dengan SEM Merk FEI tipe S50, 
EDAX AMETEK, USA. Glukomanan ditempatkan pada lempengan karbon, divakum, dan dilapisi dengan emas, serta diobservasi (Tatirat dkk., 2011).

\section{Analisis Kelarutan}

Sampel glukomanan sebanyak 0,1 g ditambah 24,9 $\mathrm{g}$ air deionisasi, diaduk dengan agitator GT seri TERRE HAU TE USA berkecepatan 150 rpm selama 1 jam. Lalu sampel disentrifugasi dengan sentrifuse tipe DAMON/ IEC Division Gerate model Appareil SW 22 pada 4000 rpm selama 20 menit untuk memisahkan bagian yang larut dan yang tidak larut. Sebanyak $10 \mathrm{~g}$ larutan bagian atas dikeringkan pada $105{ }^{\circ} \mathrm{C}$ sampai konstan (dicatat sebagai m) (Du dkk.,2012). Kelarutan dihitung dengan Persamaan 1.

Kelarutan $(\%)=m \times 2,5 / \mathrm{w} \times 100$

(Persamaan 1)

Dimana $\mathrm{m}$ adalah berat bagian larut dalam $10 \mathrm{~g}$ larutan bagian atas, dan $\mathrm{w}$ adalah berat total sampel glukomanan.

\section{Analisis Water Holding Capacity}

Sebanyak 0,1 g glukomanan dimasukkan ke dalam $50 \mathrm{~mL}$ tabung sentrifuse, selanjutnya ditambah air deionisasi sebanyak $30 \mathrm{~mL}$. Perendaman dilakukan selama 1 jam, lalu disentrifugasi 4000 rpm selama 20 menit. Supernatan dibebaskan dan sisanya ditimbang dengan neraca analitik merk Shimadzu AUW 220 Jepang. Residu ditimbang dan berat air dihitung dari selisih berat residu dengan glukomanan sebelum direndam. Perbedaan berat antara 2 pengukuran diambil sebagai berat air yang diabsorbsi. Berat dinyatakan dalam gram air/g glukomanan (Koroskenyi dan McCharty, 2001).

\section{Analisis Transparansi}

Sol glukomanan aqueous $1 \%$ setelah dinalisis viskositas apparent selanjutnya ditempatkan di kuvet spektrometer. Transparansi diukur dengan menggunakan spectrometer UV-vis pada $550 \mathrm{~nm}$ (Ye dkk., 2014) tipe thermoscientific Genesys $10 \mathrm{~S}$.

\section{Analisis viskositas Apparent}

Glukomanan 1\% dilarutkan dalam air deionisasi dan diagitasi dengan kecepatan $150 \mathrm{rpm}$ sampai terhidrasi sempuna selama 12 jam pada suhu ruang. Viskositas apparent sol diukur dengan viscometer Brookfield Model LVTDV-II pada suhu $25^{\circ} \mathrm{C}$ dengan spindle 64 setelah dibiarkan relaksasi selama 30 menit.

\section{Analisis Data}

Data dianalisis dengan menggunakan ANOVA Rancangan Acak Lengkap (RAL) dengan 3 metode penggilingan (glukomanan alami tanpa penggilingan, glukomanan penggilingan kering dan glukomanan penggilingan basah). Apabila terdapat perlakuan berbeda nyata maka perbedaannya dideterminasi dengan Uji Lanjut Duncan pada taraf 0.05.

\section{HASIL DAN PEMBAHASAN}

\section{Morfologi Permukaan Granula Glukomanan}

Morfologi glukomanan alami, glukomanan penggilingan kering dan penggilingan basah secara berturut-turut disajikan pada Gambar 1A, 1B, dan 1C. Glukomanan alami memiliki tekstur yang keras dan tahan terhadap proses mekanis selama penggilingan. Granula glukomanan alami (Gambar 1A) masih dilapisi oleh selaput tipis seperti sisik pada permukaannya dan selaput tersebut secara bertahap mengalami pengikisan yang dimulai dari permukaan luar ke arah bagian dalam secara bertahap selama proses penggilingan kering, sampai akhirnya selaput tersebut dapat dilepaskan dari glukomanan secara bertahap. Pada permukaan selaput tipis tersebut dapat juga menempel beberapa komponen non-glukomanan seperti selulosa, protein, pati dan gula serta kalsium oksalat. Pelepasan selaput ini akan menyebabkan ukuran glukomanan menjadi lebih kecil dan memiliki permukaan yang halus serta meningkatkan kadar glukomanan (Gambar 1B). Menurut Li dkk. (2009), glukomanan tersebut tersusun atas unitunit struktur lamella dimana terdapat bagian kristalin maupun amorphous. Sedangkan morfologi glukomanan penggilingan basah mengalami perubahan bentuk yang berbeda dengan glukomanan alami dan glukomanan penggilingan kering (Gambar 1C). Beberapa bagian glukomanan penggilingan basah nampak berpori dan amorf.

Perbedaan morfologi tersebut disebabkan oleh glukomanan hasil penggilingan basah berasal dari glukomanan alami yang telah mengalami proses pelarutan dimana glukomanan mengalami hidrasi dan pengembangan, selanjutnya presipitasi dengan etanol. Pada kondisi tersebut ikatan hidrogen intra dan intermolekul glukomanan lemah dan digantikan dengan ikatan hidrogen glukomanan dengan air. Pengecilan ukuran dengan proses penggilingan menjadi lebih mudah dan singkat serta depolimerisasi lebih banyak dan cepat. Dengan demikian, glukomanan penggilingan basah nampak lebih berpori dan amorf.

Glukomanan bersifat hidrofilik (Enomoto-Rogers dkk., 2014), tetapi tidak larut dalam etanol (Li dkk., 2014). Saat proses pelarutan menjadi sol $1 \%$, menurut Luo dkk. (2013) glukomanan dalam air akan mengalami hidrasi dan rantai glukomanan mengalami pengembangan 


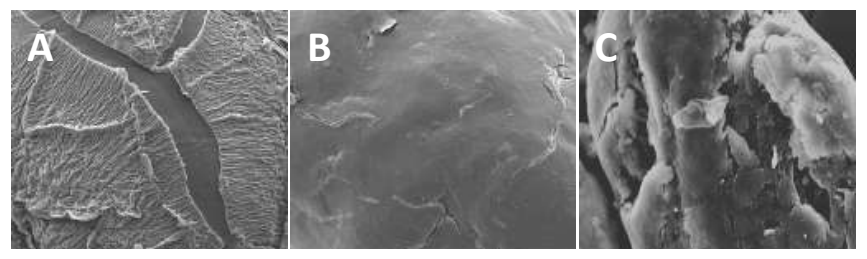

Gambar 1. SEM Granula glukomanan alami (A), hasil penggilingan kering (B) dan hasil penggilingan basah (C) dengan pembesaran $2000 x$

lebih terbuka dengan gugus asetil dapat lebih terpapar. Gugus asetil dapat menghalangi pembentukan ikatan hidrogen intra dan intermolekul glukomanan sehingga ikatan hidrogen menjadi lebih lemah. Menurut Li dkk., (2009), hidrasi air juga menyebabkan jarak daerah kristalin semakin lebar sehingga air dapat masuk dan berikatan dengan polimer membentuk ikatan hidrogen. Peningkatan ikatan hidrogen antara air dan polimer menyebabkan peningkatan kelarutan glukomanan.

Glukomanan tidak dapat larut dalam etanol (Xu dkk., 2014; Li dkk., 2014). Penambahan etanol menyebabkan penurunan polaritas (Gulseren dkk., 2012) dan glukomanan terpresipitasi. Rantai glukomanan mengalami pemadatan (Chao dkk., 2011), namun kondisinya tidak terlipat (Xu dkk., 2014) dan tetap lebih terbuka dibandingkan dengan kondisi sebelumnya. Penggilingan presipitat di saat polimer dalam keadaan lebih terbuka akan menyebabkan pemutusan rantai lebih pendek lebih mudah dan cepat. Rantai molekul yang terpotong tersebut memiliki berat molekul lebih rendah dibandingkan dengan glukomanan alami dan glukomanan penggilingan kering. Keseluruhan proses penggilingan basah ini menyebabkan glukomanan memiliki morfologi yang berbeda. Morfologi glukomanan penggilingan basah nampak memiliki rongga-rongga sehingga lebih porous (Gambar 1C) yang dapat menunjukkan lebih amorf sehingga kelarutan dan WHC meningkat secara significan (Gambar 2). Selain itu, pemutusan rantai selama penggilingan basah juga menyebabkan daerah kristalin rusak dan persentasenya menurun serta pelemahan ikatan hidrogen inter dan intrapolimer secara fisik digantikan dengan ikatan hidrogen polimer glukomanan dengan air. Peningkatan porositas, penurunan persentase kristalinitas, pelemahan ikatan hidrogen intra- dan interglukomanan yang digantikan oleh peningkatan ikatan hidrogen glukomanan dengan air berkorelasi positif dengan peningkatan kelarutan dan WHC glukomanan penggilingan basah (Gambar 2).

\section{Kelarutan Glukomanan}

Kelarutan merupakan faktor yang sangat penting dalam aplikasi industri glukomanan, baik industri pangan maupun nonpangan. Peningkatan kecepatan kelarutan glukomanan sangat diperlukan agar dapat dengan mudah dan cepat diaplikasikan di berbagai industri. Glukomanan bersifat larut dalam air, namun membutuhkan waktu lama agar lebih larut sempurna (Pan dkk., 2013). Kelarutan yang rendah dapat disebabkan oleh berat molekul glukomanan alami masih tinggi sekitar $1 \times 10^{6} \mathrm{Da}$ (Li dan Xie, 2003; Xiaoyan dkk., 2012; Yanuriati dkk., 2017a) dan ikatan hidrogen yang kuat (Liu dkk., 1998).

Kelarutan glukomanan dapat ditingkatkan secara signifikan dengan penggilingan basah maupun kering (Gambar 2) dengan peningkatan secara signifikan lebih tinggi pada glukomanan penggilingan basah (18\%) dibandingkan dengan glukomanan penggilingan kering $(13 \%)$. Selama penggilingan kering, glukomanan natif yang bersifat keras dan tahan terhadap gesekan mekanis (Zhao dkk., 2010) mengalami penyosohan dan pengecilan ukuran akibat proses pelepasan lapisan tipis yang masih menyelimuti glukomanan. Lapisan tersebut masih memiliki sejumlah kecil komponen nonglukomanan yang secara bertahap akan terlepas sehingga glukomanan menjadi lebih murni (Yanuriati dkk., 2017). Proses pelepasan selaput tersebut menyebabkan glukomanan lebih cepat larut terutama bagian amorf. Namun, peningkatan kelarutan glukomanan penggilingan kering secara signifikan masih lebih rendah dibandingkan dengan peningkatan kelarutan glukomanan penggilingan basah. Penggilingan kering memiliki konformasi struktur glukomanan lebih order (Gambar 1B) dibandingkan glukomanan penggilingan basah yang dapat dibuktikan dengan morfologi glukomanan penggilingan basah lebih berpori dan amorf (Gambar 1C). Glukomanan dengan porositas yang lebih tinggi memiliki persentase derajat kristalinitas lebih rendah dan ikatan hidrogen yang lebih lemah sehingga lebih mudah larut.

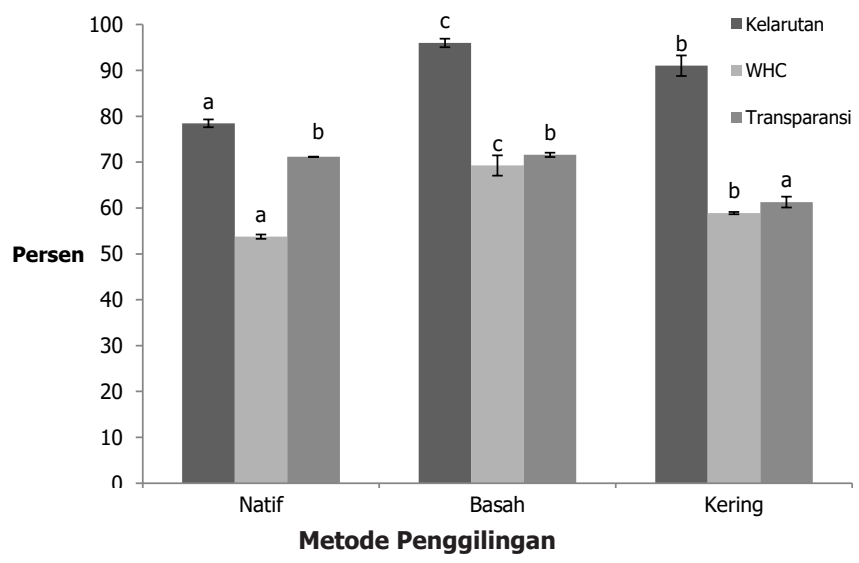

Gambar 2. Kelarutan, transparansi dan WHC glukomanan natif, penggilingan basah dan penggilingan kering. Huruf yang sama pada parameter yang sama menunjukkan perbedaan yang tidak signifikan 
Selain itu, penggilingan basah dapat menyebabkan pemotongan rantai molekul glukomanan sehingga memiliki berat molekul lebih rendah dan lebih terbuka dengan gugus asetil dapat mengurangi kekuatan ikatan hidrogen. Penurunan berat molekul dapat dikorelasikan dengan penurunan viskositas apparent yang ditampilkan pada Gambar 3. Berat molekul yang lebih rendah menyebabkan kelarutan glukomanan penggilingan basah meningkat secara signifikan lebih besar mencapai 96\% dibandingkan dengan glukomanan hasil penggilingan kering yang mencapai $91 \%$ dari sebelumnya hanya $78 \%$ pada glukomanan natif tanpa penggilingan. Rantai glukomanan yang lebih pendek dengan adanya gugus $\mathrm{OH}$ yang terasetilasi menyebabkan ikatan hidrogen intra and intermolekul lebih lemah. Kondisi ini memudahkan air untuk menggantikan ikatan hidrogen inter dan intramolekul tersebut (Pan dkk., 2011) sehingga kecepatan kelarutan meningkat secara signifikan. Penurunan berat molekul didukung dengan penurunan viskositas apparent (Gambar 3). Penurunan viskositas apparent dapat mengindikasikan telah terjadi penurunan berat molekul akibat pemotongan rantai glukomanan selama penggilingan basah. Menurut Luo dkk. (2012), penurunan berat molekul meningkatkan kelarutan glukomanan. Glukomanan dengan berat molekul yang lebih rendah memiliki struktur yang kurang kompak dan lebih amorf sehingga kelarutan lebih tinggi.

\section{Water Holding Capacity}

WHC glukomanan baik penggilingan basah maupun kering secara signifikan dapat ditingkatkan, dengan peningkatan secara signifikan lebih besar terjadi pada WHC glukomanan dengan cara penggilingan basah (Gambar 2). Glukomanan tersusun dari satuan-satuan struktur lamela yang memiliki area berstruktur kristalin dan amorf. Area berstruktur amorf (Prawitwong dkk., 2007) akan lebih cepat larut dibandingkan dengan area berstruktur kristalin (Li dkk., 2009). Glukomanan penggilingan basah memiliki morfologi lebih amorf (Gambar 1C) yang berarti gelukomanan tersebut memiliki ikatan hidrogen intra dan intermolekul lebih lemah dibandingkan glukomanan penggilingan kering yang memiliki morfologi lebih kompak (Gambar 1B). Ikatan hidrogen intra dan intermolekul yang lemah pada glukomanan penggilingan basah menyebabkan air dapat menggantikan ikatan intra dan inter glukomanan tersebut. Peningkatan ikatan hidrogen antara air dengan glukomanan mengkontribusi peningkatan WHC glukomanan penggilingan basah yang lebih besar dibandingkan dengan WHC penggilingan kering.

Dalam air, hidrasi glukomanan menyebabkan pengembangan rantai dan dimensi molekul menjadi lebih besar (Luo dkk., 2013). Pengenceran glukomanan dengan air menyebabkan pengembangan rantai molekul lebih besar sehingga pada kondisi demikian gugus asetil akan lebih terekspose dan mengurangi kekuatan ikatan hidrogen antar glukomanan sehingga penggilingan pada kondisi isolat tersebut menyebabkan rantai molekul dapat terpotong lebih banyak dan berukuran lebih pendek. Pemutusan rantai molekul dapat menyebabkan penurunan berat molekul serta melemahkan ikatan hidrogen inter- dan intra molekul glukomanan sehingga rantai glukomanan lebih cepat terhidrasi membentuk ikatan hidrogen dengan air dan menyebabkan peningkatan WHC.

Penggilingan kering glukomanan alami dapat mengikis permukaan struktur lamella baik amorf maupun kristalin. Proses penggilingan kering sampai ukuran menjadi 80 mesh membutuhkan waktu yang lama dan penggiling berkecepatan tinggi. Glukomanan penggilingan kering mengalami pengecilan ukuran dengan proses pengikisan selaput tipis pada permukaan yang menyelubungi glukomanan dari permukaan luar ke arah bagian dalam glukomanan yang sangat kompak, tidak mengembang seperti yang terjadi pada penggilingan basah, sehingga glukomanan tersebut tetap memiliki berat molekul lebih tinggi dan hidrasi lebih lambat dibandingkan dengan glukomanan penggilingan basah. Selain itu, selama proses penggilingan tersebut juga akan menimbulkan panas dan dalam periode kritis dapat menimbulkan degradasi pada glukomanan akibat panas kumulatif yang ditimbulkan, serta dapat menyebabkan ikatan hidrogen dalam dan antar molekul meningkat, sehingga peningkatan WHC menjadi lebih rendah dibandingkan dengan penggilingan basah.

\section{Transparansi Sol Glukomanan}

Transparansi (kebeningan) sol yang tinggi merupakan faktor penting agar aplikasinya pada produk tidak berpengaruh terhadap penampakan produk yang ditambahkan, terutama pada produk pangan dan kosmetika. Sol glukomanan alami dengan proses isolasi yang dilakukan nampak memiliki tranparansi yang tinggi. Transparansi sol tersebut masih dapat dipertahankan tetap tinggi dengan penggilingan basah. Sedangkan tranparansi sol glukomanan penggilingan kering mengalami penurunan signifikan (Gambar 2).

Penggilingan glukomanan secara kering menyebabkan pelepasan selaput yang menyelimuti permukaan glukomanan natif secara bertahap (Gambar 1B). Pelepasan selaput tersebut juga menyebabkan pelepasan komponen non glukomanan yang masih tersisa melekat dipermukaan glukomanan seperti pati, protein, selulosa dan kalsium oksalat. Pelepasan komponen-komponen tersebut seharusnya akan meningkatkan kadar glukomanan dan juga transparansi 
sol glukomanan. Namun, transparansi sol glukomanan hasil penggilingan kering menurun secara signifikan.

Penurunan tranparansi sol dapat disebabkan oleh proses penggilingan glukomanan kering membutuhkan waktu relatif lama dengan penggiling berkecepatan tinggi. Glukomanan bertekstur keras (Zhao dkk., 2010) dan tahan terhadap gesekan mekanis yang terjadi selama penggilingan sehingga penggilingan kering membutuhkan waktu yang relatif sangat lama. Saat mencapaiperiodekritis, penggilingankeringmenghasilkan panas kumulatif yang dapat mengakibatkan glukomanan berubah warna menjadi lebih gelap sebagai akibat dari oksidasi glukomanan dari panas kumulatif yang terjadi selama penggilingan. Perubahan glukomanan menjadi lebih gelap menyebabkan penurunan tranparansi sol secara signifikan. Sebaliknya, tranparansi sol glukomanan penggilingan basah cenderung lebih stabil yang dapat disebabkan oleh glukomanan penggilingan basah berlangsung cepat sehingga panas kumulatif dalam periode singkat belum menyebabkan oksidasi glukomanan, sehingga glukomanan tidak mengalami perubahan warna menjadi lebih gelap.

Selain itu, kestabilan transparansi sol glukomanan penggilingan basah juga dapat disebabkan oleh proses pelarutan glukomanan dengan akuademin yang diikuti presipitasi glukomanan dengan etanol menghasilkan glukomanan lebih bersih. Sisa komponen nonglukomanan akan leaching ke etanol dan terbuang bersama etanol. Selain itu, pemotongan rantai molekul yang lebih terbuka selama penggilingan basah menyebabkan rantai polimer lebih pendek dan berat molekul menurun bersamaan dengan penurunan persentase kristalinitas. Perubahan tersebut menghasilkan entanglement rantai glukomanan yang terbentuk dalam sol pada konsentrasi yang sama lebih sedikit dibandingkan dengan glukomanan penggilingan kering, sehingga glukomanan penggilingan basah memiliki tranparansi tetap tinggi. Glukomanan yang memiliki berat molekul yang lebih rendah akan lebih bebas bergerak tanpa tumpang tindih (Ojima dkk., 2009) dan mengalami pengembangan lebih besar pada konsentrasi yang lebih rendah (Long dkk., 2010). Sedangkan pada konsentrasi yang lebih tinggi, interaksi antara polimer tumpang tindih (overlap) satu sama lain akan meningkat sampai akhirnya mengalami pengerutan pada konsentrasi kritis dimana koil polimer mencapai ukuran yang terbatas (Ojima dkk., 2009) yang dapat mempengaruhi penurunan tranparansi glukomanan.

\section{Viskositas Apparent Glukomanan}

Glukomanan alami memiliki viskositas apparent yang tinggi sehingga bila diaplikasikan sebagai pembentuk gel atau pengental pada makanan akan membutuhkan konsentrasi yang rendah. Yanuriati dkk. (2017b) menemukan bahwa sinergi pembentukan gel glukomanan dengan xantan membutuhkan konsentrasi glukomanan yang lebih kecil bila glukomanan memiliki viskositas apparent yang tinggi.

Perubahan viskositas apparent dapat dikorelasikan dengan perubahan interaksi inter- dan intrapolimer dan perubahan konformasi polimer dalam larutan aqueous (Lee dkk., 2015). Glukomanan alami memiliki viskositas paling tinggi (85.515 cps). Viskositas apparent glukomanan penggilingan basah mengalami penurunan signifikan (Gambar 3), sedangkan viskositas apparent glukomanan penggilingan kering cenderung stabil tidak berbeda nyata dengan glukomanan natif.

Glukomanan dapat larut dalam air (Ojima dkk., 2009; Jiang dkk., 2018; Li dkk., 2014). Glukomanan dalam air akan terhidrasi sehingga rantainya mengalami pengembangan lebih terbuka. Pengembangan rantai polimer semakin besar terjadi pada konsentrasi yang lebih rendah. Pada konsentrasi yang lebih tinggi, ruang bebas rantai molekul polimer akan menjadi semakin sempit, sehingga interaksi antar dan interpolimer terjadi semakin meningkat (Long dkk., 2010; Luo dkk., 2013). Peningkatan interaksi polimer tersebut menyebabkan peningkatan ikatan hidrogen, tumpang tindih (overlapping) dan entanglement rantai glukomanan. Peningkatan ikatan hidrogen inter- dan intrapolimer, overlapping dan entanglement rantai glukomanan menyebabkan peningkatan viskositas apparent (Luo dkk., 2013; He dkk., 2012).

Penurunan viskositas apparent secara signifikan pada glukomanan penggilingan basah (Gambar 3) dapat terjadi akibat penurunan berat molekul. Viskositas glukomanan sangat berkorelasi dengan berat molekul (Luo dkk,., 2012). Rantai glukomanan penggilingan basah mengalami hidrasi dan ekspansi. Glukomanan dengan kondisi demikian memiliki ikatan hidrogen yang lemah sehingga penggilingannya dapat berlangsung

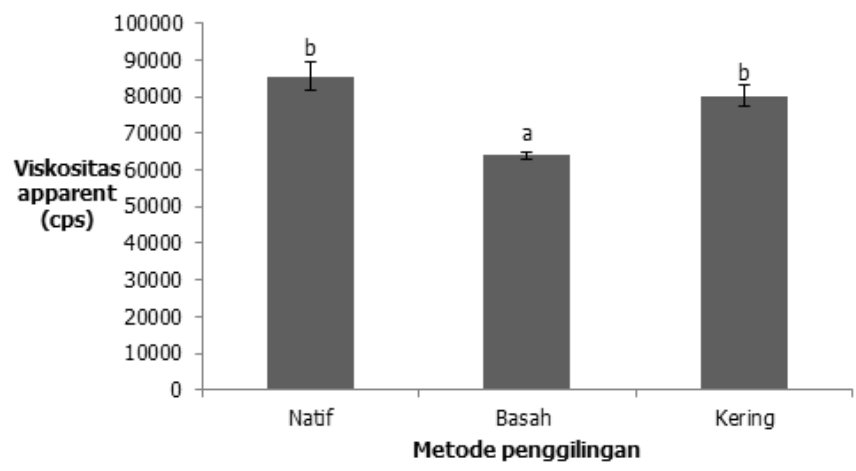

Gambar 3. Histogram viskositas apparent glukomanan natif, penggilingan basah dan kering. Huruf yang sama menunjukkan perbedaan tidak signifikan 
dengan mudah dan cepat disertai pemutusan rantai terjadi lebih banyak. Glukomanan penggilingan basah yang dihasilkan mengalami penurunan berat molekul tanpa menyebabkan degradasi glukomanan, yang dibuktikan dengan transparansinya yang masih tinggi (Gambar 2). Rantai glukomanan dengan berat molekul yang lebih kecil dalam air akan terekspansi lebih besar dan memiliki entanglement lebih sedikit sehingga dapat menyebabkan penurunan pada viskositas apparent.

\section{KESIMPULAN}

Penggilingan basah dapat meningkatkan kelarutan glukomanan secara signifikan lebih tinggi (18\%) dibandingkan penggilingan kering (13\%) dengan transparansi, WHC dan viskositas apparent masih tinggi. Peningkatan kelarutan secara signifikan menggunakan penggilingan basah disebabkan oleh perubahan morfologi glukomanan lebih porous, depolimerisasi dengan mudah dan cepat, sehingga glukomanan penggilingan basah memiliki rantai polimer dan berat molekul lebih kecil dengan konformasi rantai lebih terbuka, yang dapat dikorelasikan dengan penurunan signifikan terhadap viskositas apparent. Meskipun demikian, viskositas apparentnya masih tetap tinggi.

\section{UCAPAN TERIMA KASIH}

Ucapan terima kasih diberikan kepada Kementrian, Teknologi dan Pendidikan Tinggi Republik Indonesia yang telah memberikan bantuan dana penelitian ini pada Program Penelitian Fundamental pada tahun anggaran 2017 dengan nomor: 453/UN9.3.1/LT/2017.

\section{KONFLIK KEPENTINGAN}

Tidak ada terdapat konflik kepentingan pada publikasi ini.

\section{DAFTAR PUSTAKA}

Alonso-Sande, M., Teijeiro-Osorio, D., Remuñán-López, C., \& Alonso, M. J. (2009). Glucomannan, a promising polysaccharide for biopharmaceutical purposes. European Journal of Pharmaceutics and Biopharmaceutics, 72(2), 453-462. https://doi.org/10.1016/j.ejpb.2008.02.005

An, N. T., Dong, N. T., Dung, P. L., \& Thien, D. T. (2011) a. Synthesis dan characterization of water-soluble O-carboxymethyl glucomannan derivatives. Carbohydrate Polymers, 83(2), 645-652. https://doi. org/10.1016/j.carbpol.2010.08.034
An, N. T., Thien, D. T., Dong, N. T., Dung, P., Le \& Du, N. Van. 2011b. Isolation dan characteristics of polysaccharide from Amorphophallus corrugatus in Vietnam. Carbohydrate Polymers, 84(1), 64-68. https://doi. org/10.1016/j.carbpol.2010.10.074

Behera, S.S., \& Ray, R.C. (2016). Konjac glucomannan, a promising polysaccharide of Amorphophallus konjac K.Koch in health care. International Journal of Biological Macromolecules, 92, 942-956. http://dx.doi.org/10.108 $0 / 87559129.2015 .1137310$

Chao, W., Xiao-ling, Chen, Z.M., Li, D., \& Lv, W. P. (2011). Structure dan Properties of Konjac Glucomannan Solved in Alcohol/Water. Advanced Materials Research, 198, 1310-1314. https://doi.org/10.4028/www.scientific.net/ AMR.197-198.1310

Chao, W., Mei, X., Wen-ping, L., Pei, Q., Yuan-yuan, G., \& Dong-sheng, L. (2012). Study on Rheological Behavior of Konjac Glucomannan. Physics Procedia, 33, 25-30. https://doi.org/10.4028/www.scientific.net/AMM.5254.1344

Chua, M., Baldwin, T.C., Hocking, T.J., \& Chan, K. (2010). Traditional uses dan potential health benefits of Amorphophallus konjac K. Koch ex N.E. Br. Journal of Ethnopharmacology, 128, 268-278. https://doi. org/10.1016/j.jep.2010.01.021

Du, X., Li, J., Chen, J., \& Li, B. (2012). Effect of degree of deacetylation on physicochemical dan gelation properties of konjac glucomannan. Food Research International, 46(1), 270-278. https://doi.org/10.1016/j. jep.2010.01.021

Enomoto-rogers, Y., Ohmomo, Y., Takemura, A., \& Iwata, T. (2014). Syntheses of glucomannan esters dan their thermal dan mechanical properties. Carbohydrate Polymers, 101, 592-599. http://dx.doi.org/10.1016/j. carbpol.2013.09.103

Gao, S., \& Nishinari, K. (2004). Effect of degree of acetylation on gelation of konjac glucomannan. Biomacromolecules, 5, 175-185. https://doi.org/10.1016/j. colsurfb.2004.02.026

Gulseren, I., Yuan, F., \& Corredig. (2012). Whey protein nanoparticle prepared with desolvation with ethanol: characterization thermal stability dan interfacial behavior. Food Hydrocolloid, 29, 258-264.

He, P., Luo, X., Lin, X., \& Zhang, H. (2012). The rheological properties of konjac glucomannan (KGM) solution. Material Science Forum, 724, 57-60. https://doi. org/10.4028/www.scientific.net/MSF.724.57

Jiang, M., Li, H., Shi, J., \& Xu, Z. (2018). Depolymerized konjac glucomannan: preparation dan application in health care. Journal of Zhejiang University-Science $B$ (Biomedicine \& Biotechnology), 19(7), 505-514. https:// doi.org/10.1631/jzus.B1700310 
Koroskenyi, B., \& McCharty, S.P. (2001). Synthesis of acetylated konjac glucomannan dan effect of degree of acetylation on water absorbency. Biomacromolecules, 2, 824-826. https://doi.org/10.1021/bm010014c

Li, J., Ye, T., Wu, X., Chen, J., Wang, S., Lin, L., \& Li, B. (2014). Preparation dan characterization of heterogeneous deacetylated konjac glucomannan. Food Hydrocolloids, 40, 9-15. http://dx.doi.org/10.1016/j. foodhyd.2014.02.001

Li, B., \& Xie, B. (2003). Study on gel formation mechanism of konjac glucomannan. Agricultural Sciences in China, 2(4), 424-428. https://doi.org/10.1021/jf050751q

Li, B., Xie, J., Wang, Y., \& Xie, B.J. (2005). Grain-size effect on the structure dan antiobesity activity of konjac flour. Journal of Agriculture dan Food Chemistry, 53, 74047407. https://doi.org/10.1021/jf050751q

Li, B., \& Xie, B. (2006). Single molecular chain geometry of konjac glucomannan as a high dietary fiber in East Asia. Food Research International, 39, 127-132. https://doi .org/10.1016/j.foodres.2004.12.002

Li, L., Ruan, H., Ma, L., Wang, W., Zhou, P., \& He, G. (2009). Study on swelling model dan thermodynamic structure of alami konjac glucomannan. Journal of Zhejiang University, Science. B, 10(4), 273-279. https://doi. org/10.1631/jzus.B0820221

Lee, M.E., Lee, H.D., \& Suh, H.H. (2015). Production dan characterization of extracellular polysaccharide produced by Preudomonas sp. GP32. Journal of Life Science, 25, 1027-1035.

Lin-Lin, F., Shu-Hui, P., Cheng-Rong, W., Ming-Xiang, H., XueQi, W., Chun-Hua, W., Min-Na, Y., Rui, F., \& Jie, P. (2012). Analysis of influential factors of konjac glucomannan (GMK) molecular structure on its activity. Chinese Journal of Structural Chemistry, 31(4), 605-613. https:// doi.org/10.1021/jf050751q

Liu, Jiang-yun, Wang, Hu-cheng, Yin, Y., Li, N., Cai, Pei-lie., \& Yang, Shi-lin. (2012). Controlled acetylation of water soluble glucomannan from Bletilla striata. Carbohydrate Polymers, 89, 158-162.

Liu, P., Zhang, S., \& Zhang, X. (1998). Research dan utilization of Amorphophallus in China. Acta Botanica Yunnanica, $X, 48-61$. https://doi.org/10.1016/j.carbpol.2012.02.065

Luo, X., He, P., \& Lin, X. (2013). The mechanism of sodium hydroxide solution promoting the gelation of konjac glucomannan (KGM). Food Hydrocolloids, 30(1), 92-99.

Luo, X., Yao, X., Zhang, C., Lin, X., \& Han, B. (2012). Preparation of mid-to-high molecular weight konjac glucomannan (MHKGM) using controllable enzymecatalyzed degradation dan investigation of MHKGM properties. Journal of Polymer Research, 19(4), 98499858. https://doi.org/10.1016/j.carbpol.2012.02.065
Long, X., Luo, X., Bai, J., \& Zhu, J. (2010). Studies on the molecular chain conformation dan morphology of konjac glucomannan in aqueous solution. Material Science Forum, 658, 388-391. https://doi.org/10.4028/www. scientific.net/MSF.658.388

Ohashi, S., Shelso, G.J., Moirano, D., Arthur, L., \& Drinkwater, W.L. (2000). Clarified konjac glucomannan. United States Patent, 6,162,906 (Des 10).

Ojima, R., Makabe, T., Prawitwong, P., Takahashi, R., Takigami, M., \& Takigami, S. (2009). Rheological Property of Hydrolyzed Konjac Glucomannan. Transaction of the Materials Research Society of Japan, 34(3), 477-480.

Pan, Z., Meng, J., \& Wang, Y. (2011). Effect of alkalis on deacetylation of konjac glucomannan in mechanochemical treatment. Particulogy, 9, 265-269. doi:10.1016/j.partic.2010.11.003

Pan, T., Peng, S., Xu, Z., Xiong, B., Wen, C., Yao, M., \& Pang, J. (2013). Synergetic degradation of konjac glucomannan by $\mathrm{Y}$-ray irradiation dan hydrogen peroxide. Carbohydrate Polymers, 93, 761-767. doi:10.1016/j. carbpol.2012.11.075

Prawitwong, P., Takigami, S., \& Phillips, G. O. (2007). Phase transition behaviour of sorbed water in konjac mannan. Food Hydrocolloids, 21(8), 1368-1373. doi:10.1016/j. foodhyd.2006.10.017

Tatirat, O., Charunuch, C., Kerr, W.L., \& Charoenrein. (2013). Use of ethanol solution for extruding konjac glucomannan to modify its water absorption dan water solubility. Kasetsart Journal (Natural Science), 47, 132142.

Tester, R.F., \& Al-Ghazzewi, F.H. (2013). Mannans dan health, with a special focus on glucomannans. Food Research International, 50, 384-391. http://dx.doi.org/10.1016/j. foodres.2012.10.037

Wang, C., Zhu, Y., Xu, M., LI, D., \& Huang, H. (2011). Study on molecule dimension of different granularity Konjac glucomannan. Applied Mechanics dan Materials, 52-54, 1344-1347. doi:10.4028/www.scientific.net/AMM.5254.1344

Xiaoyan, L., Qiang, W., Xuegang, L., Feng, L., Xiaoqing, L., \& Pan, H. (2010). Effect of degree of acetylation on thermoplastic dan melt rheological properties of acetylated konjac glucomannan. Carbohydrate Polymers, 82, 167-172. doi:10.1016/j.carbpol.2010.04.053

Xing, X., Cui, S.W., Nie, S., Phillips, G.O., Goff, H.D., \& Wang, Q. (2015). Study on Dendrobium officinale O-acetylglucomannan (Dendronan): Part II. Fine structures of O-acetylated residues. Carbohydrate Polymers, 117, 422-433. http://dx.doi.org/10.1016/j.bcdf.2014.12.005

Xu, W., Wang, Y., Jin, W., Wang, S., Zhou, B., Li, J., Li, B., \& Wang, L. 2014. A One-step procedure for elevating the quality of konjac flour: Azeotropy-assisted acidic 
alcohol. Food Hydrocolloids, 35, 653-660. https://doi. org/10.1016/j.foodhyd.2013.08.014

Ye, T., Wang, L., Xu, W., Liu, J., Wang, Y., Zhu, K., \&Wang, C. (2014). An approach for prominent enhancement of the quality of konjac flour: Dimethyl sulfoxide as medium. Carbohydrate Polymers, 99, 173-179. http://dx.doi. org/10.1016/j.carbpol.2013.08.038

Yanuriati, A., Djagal, W.M, Rochmadi, \& Harmayani, E. (2017a). Characteristics of glucomannan isolated from fresh tuber of porang (Amorphophallus muelleri Blume). Carbohydrate Polymers, 156, 56-63. http://dx.doi. org/10.1016/j.carbpol.2016.08.080

Yanuriati, A., Djagal, W.M, Rochmad, \& Harmayani, E. (2017b). Gel glukomanan porang-xantan dan kestabilannya setelah penyimpanan dingin dan beku. agriTECH, 37(2), 121-131. DOI: http://doi.org/10.22146/agritech.10793
Zhang, C., Chen, J. Da., \& Yang, F. Q. (2014). Konjac glucomannan, a promising polysaccharide for OCDDS. Carbohydrate Polymers 104(1), 175-181. http://dx.doi. org/10.1016/j.carbpol.2013.12.081

Zhang, Y. Q., Xie, B. J., \& Gan, X. (2005). Advance in the applications of konjac glucomannan dan its derivatives. Carbohydrate Polymers, 60(1), 27-31. doi:10.1016/j. carbpol.2004.11.003

Zhao, J., Zang, D., Srzednicki, G., Kanlayanarat, S., \& Borompichaichartkul, C. (2010). Development of a lowcost two-stage technique for production of low-sulphur purified konjac flour. International Food Research Journal, 17, 1113-1124. 